\title{
Production and transepithelial transportation of angiotensin-l-converting enzyme (ACE)-inhibitory peptides from whey protein hydrolyzed by immobilized Lactobacillus helveticus proteinase
}

\author{
Yuxing Guo, ${ }^{1}$ Xiaoxiao Jiang, ${ }^{1}$ Binyi Xiong, ${ }^{1}$ Tao Zhang, ${ }^{1}$ Xiaoqun Zeng, ${ }^{2}$ Zhen $W u,{ }^{2}$ Yangying Sun, ${ }^{2}$ \\ and Daodong Pan ${ }^{1,2 *}$ \\ ${ }^{1}$ Department of Food Science and Technology, Ginling College, Nanjing Normal University, Nanjing 210097, Jiangsu, China \\ ${ }^{2}$ Food Science and Technology Department, Marine Science School, Ningbo University, Ningbo 315211, Zhejiang, China
}

\section{ABSTRACT}

Lactobacillus helveticus LB 10 proteinases immobilized with sodium alginate were used to hydrolyze whey protein to produce angiotensin-I-converting enzyme (ACE)-inhibitory peptides. The generated hydrolysates were tested for ACE-inhibitory activity and for their ability to be transported across Caco-2 cell monolayers. Using a response surface method, we determined that a proteinase concentration of $7.55 \mathrm{mg} / \mathrm{mL}$, sodium alginate concentration of $2.03 \mathrm{~g} / 100 \mathrm{~mL}$, and glutaraldehyde concentration of $0.39 \%$ were found to be the optimal immobilization conditions. Compared with free proteinase, the immobilized proteinase had significantly higher $\mathrm{pH}$, thermal and storage stability, and reusability. Whey protein hydrolysates were fractionated by gel filtration chromatography and ACE-inhibitory peptide mixtures were transported across Caco-2 cell monolayers in a human intestinal-absorption model. The di- and tripeptides KA, EN, DIS, EVD, LF, AIV, and VFK (half-maximal inhibitory concentrations (mean \pm standard deviation) of $1.24 \pm 0.01,1.43 \pm 0.04,1.59$ $\pm 0.27,1.32 \pm 0.05,1.60 \pm 0.39,2.66 \pm 0.02$, and $1.76 \pm 0.09 \mathrm{mmol} / \mathrm{L}$, respectively) were detected on the basolateral side of the Caco-2 cell monolayer using ultra-performance liquid chromatography-tandem mass spectrometry. These results highlight that ACEinhibitory peptides are present on the basolateral side of the Caco-2 cell model after transportation of whey protein hydrolysate across the Caco-2 cell membrane. Key words: angiotensin-I-converting enzyme (ACE)inhibitory peptide, proteinase, Lactobacillus helveticus, Caco-2 cell, bioavailability

Received April 9, 2018.

Accepted October 31, 2018.

*Corresponding author: daodongpan@163.com

\section{INTRODUCTION}

Angiotensin-I-converting enzymes (ACE; EC 3.4.15.1) play an important role in modulating blood pressure: ACE converts inactive angiotensin I into angiotensin II (a potent octapeptide vasoconstrictor), which can increase blood pressure. Angiotensin-Iconverting enzymes can also degrade the vasodilator peptide bradykinin (Stuknytè et al., 2015). Therefore, ACE-inhibitory peptides may be used as a nutraceutical to prevent or manage hypertension.

Lactobacillus helveticus is a thermophilic lactic acid bacterium widely used in the manufacture of dairy products such as cheese and fermented milk (Sadat-Mekmene et al., 2011). Some studies have found that milk fermented with L. helveticus exhibits ACE-inhibitory activity, which is due to the specific proteolytic activity of L. helveticus (Nakamura et al., 1995, Yamamoto et al., 1999). Cell-envelope proteinase (CEP), a key enzyme in the proteolytic system of Lactobacillus, hydrolyzes protein into different oligopeptides (Sadat-Mekmene et al., 2011). The hydrolysates can be transported across the cell membrane by AA transport systems, including oligopeptide and di- and tripeptide transporters. Then, the peptides are further hydrolyzed into AA or smaller peptides by intracellular peptidases, including endopeptidases, aminopeptidases, and X-prolyl-dipeptidyl aminopeptidases (Pan and Guo, 2010; Wakai et al., 2013). Wakai et al. (2013) reported that CEP affects the production of VPP $[\beta-\mathrm{CN} f(84-86)]$ and IPP $[\beta-$ CN f(74-76)] from milk protein, and Guo et al. (2009) identified RLSFNP, a new ACE-inhibitory peptide from whey protein hydrolyzed by crude proteinases (cell-free extracts containing CEP and peptidases) of L. helveticus LB 10. However, ACE-inhibitory peptide production using free L. helveticus LB 10 proteinases is expensive because of the difficulty in extracting the proteinases. Therefore, in this study, we immobilized $L$. helveticus LB 10 proteinases to produce ACE-inhibitory peptides from whey protein. 
One of the greatest challenges in developing milk peptides as antihypertensive food ingredients has been proving their in vivo efficacy (Hernández-Ledesma et al., 2014). To exert an antihypertensive effect after oral administration, ACE-inhibitory peptides must remain active after intestinal transport and at least until they reach the cardiovascular system (Fernández-Musoles et al., 2013). Most ACE-inhibitory peptides have between 2 and 12 AA (Stuknyte et al., 2015). Among ACEinhibitory peptides, several di- and tripeptides, such as VPP and IPP, have been reported to be inhibitors that can be transported intact across the intestinal epithelium (Nakamura et al., 1995). However, long-chain ACE-inhibitory peptides may have difficulty crossing the intestinal epithelial cell barrier and thereby lose their antihypertensive capabilities in vivo (Vermeirssen et al., 2002). The antihypertensive peptide YAEERYPIL was completely hydrolyzed into YAEER and YP by peptidases in the intestinal brush-border membrane (Miguela et al., 2007). The ACE-inhibitory peptide RLSFNP was hydrolyzed into fragments (F, FNP, SFNP, and RLSF) when it crossed Caco-2 cell monolayers (Guo et al., 2018). The intestinal transport of ACE-inhibitory peptides is an important factor in the in vitro investigation of the maintenance of ACEinhibitory activity through the oral pathway (Vermeirssen et al., 2002).

The Caco- 2 cell model can be used to study absorption of ACE-inhibitory peptides and to screen transportable ACE-inhibitory peptides. The transport of milk-derived peptide mixtures across Caco- 2 cell monolayers has been reported (Stevenson et al., 1999). Caco2 cells, which are derived from human intestinal adenocarcinoma, exhibit spontaneous enterocyte-like differentiation, microvillus structure, and functional tight junctions between adjacent cells, as well as transport systems, cellular peptidases, and other characteristics that mimic human intestinal epithelial cell absorption (Sonnier et al., 2010; Picariello et al., 2013).

The bioavailability of milk-derived peptides is a major issue that may hamper their use as bioactive ingredients in functional dairy foods. The objective of the present research was to produce ACE-inhibitory peptides hydrolyzed from whey protein using immobilized L. helveticus proteinases and to study transepithelial transportation of ACE-inhibitory peptides in a Caco2 cell model. Immobilized proteinases of $L$. helveticus were used as catalytic agents to hydrolyze whey protein into ACE-inhibitory peptides. The hydrolysate was fractionated using gel filtration chromatography and the low-molecular-mass fraction having ACE-inhibitory activity was then presented to Caco- 2 monolayers to assess the ability of the peptides to cross the intes- tinal barrier. The peptides present in the basolateral solution were identified using ultra-performance liquid chromatography-tandem mass spectrometry (UPLCMS/MS). The detected peptides were synthesized and their ACE-inhibitory activity was analyzed.

\section{MATERIALS AND METHODS}

\section{Preparation of Cell-Free Proteinases from L. helveticus}

Lactobacillus helveticus LB10 (conserved by the Dairy Biotechnology Key Laboratory, Nanjing Normal University, Nanjing, Jiangsu, China) was grown in liquid de Man, Rogosa, and Sharpe broth at $37^{\circ} \mathrm{C}$ for 24 $\mathrm{h}$. The L. helveticus culture medium was centrifuged $\left(4,500 \times g, 20 \mathrm{~min}, 4^{\circ} \mathrm{C}\right)$ to harvest the cells, which were then washed 3 times with Tris- $\mathrm{HCl}$ buffer (50 $\mathrm{m} M, \mathrm{pH}$ 7.1). The washed cells were suspended in Tris$\mathrm{HCl}$ buffer $(50 \mathrm{mM}, \mathrm{pH} 7.1)$ at a final concentration of $0.2 \mathrm{~g} / \mathrm{mL}$, and then treated with ultrasonic waves (300 W) at 30-s intervals for $26 \mathrm{~min}$ at $4^{\circ} \mathrm{C}$. To remove the cell debris, the samples were centrifuged at $4,500 \times g$ for $20 \mathrm{~min}$ at $4^{\circ} \mathrm{C}$. The supernatant containing cell-free proteinases was collected.

\section{Immobilization of L. helveticus Proteinases}

Proteinase Immobilization. The proteinases were immobilized under sterile conditions. Sodium alginate was suspended in proteinase solution. The mixture was extruded dropwise through a syringe into $\mathrm{CaCl}_{2}$ solution. The capsules were hardened for $4 \mathrm{~h}$ at $4^{\circ} \mathrm{C}$ and then washed with sterile distilled water. Glutaraldehyde was added to crosslink the proteinases in capsules for 6 $\mathrm{h}$. The capsules were washed again with sterile distilled water and used as immobilized proteinases. The factors (sodium alginate, $\mathrm{CaCl}_{2}$, glutaraldehyde, and proteinase concentrations) were optimized using a single-factor experiment and response surface methodology (RSM). The activity of the immobilized proteinases was analyzed according to the method described below.

Single-Factor Experiment. The effect of sodium alginate on the activity of the immobilized proteinases was studied at concentrations of 1, 1.5, 2, 2.5, and 3 $\mathrm{g} / 100 \mathrm{~mL}$. The effect of $\mathrm{CaCl}_{2}$ on immobilized proteinase activity was studied at concentrations of $0.05,0.1$, $0.15,0.2$, and $0.25 \mathrm{~mol} / \mathrm{L}$. The effect of glutaraldehyde on immobilized proteinase activity was conducted at concentrations of $0.2,0.4,0.6,0.8$, and $1.0 \%$. The effect of proteinase concentration on immobilized proteinase activity was conducted at concentrations of $4,8,12,16$, and $20 \mathrm{mg} / \mathrm{mL}$. 
Table 1. Experimental design used in the response surface method (RSM) studies with 3 independent variables showing observed specific immobilized proteinase activity $(\% ; y)$

\begin{tabular}{lcccc}
\hline & \multicolumn{3}{c}{ Variable $^{1}$} & \\
\cline { 2 - 3 } Run & $x_{1}$ & $x_{2}$ & $x_{3}$ & $\begin{array}{c}\text { Specific immobilized } \\
\text { proteinase activity (U/mg) }\end{array}$ \\
\hline 1 & $4(-1)$ & $1.5(-1)$ & $0.4(0)$ & 1.95 \\
2 & $12(1)$ & $1.5(-1)$ & $0.4(0)$ & 1.33 \\
3 & $4(-1)$ & $2.5(1)$ & $0.4(0)$ & 1.95 \\
4 & $12(1)$ & $2.5(1)$ & $0.4(0)$ & 1.90 \\
5 & $4(-1)$ & $2(0)$ & $0.2(-1)$ & 1.98 \\
6 & $12(1)$ & $2(0)$ & $0.2(-1)$ & 1.32 \\
7 & $4(-1)$ & $2(0)$ & $0.6(1)$ & 1.04 \\
8 & $12(1)$ & $2(0)$ & $0.6(1)$ & 2.06 \\
9 & $8(0)$ & $1.5(-1)$ & $0.2(-1)$ & 1.99 \\
10 & $8(0)$ & $2.5(1)$ & $0.2(-1)$ & 1.33 \\
11 & $8(0)$ & $1.5(-1)$ & $0.6(1)$ & 4.91 \\
12 & $8(0)$ & $2.5(1)$ & $0.6(1)$ & 3.73 \\
13 & $8(0)$ & $2(0)$ & $0.4(0)$ & 3.90 \\
14 & $8(0)$ & $2(0)$ & $0.4(0)$ & \\
15 & $8(0)$ & $2(0)$ & $0.4(0)$ & \\
\hline
\end{tabular}

${ }^{1}$ The independent variables were concentrations of proteinase $\left(x_{1}\right)$, sodium alginate $\left(x_{2}\right)$ and glutaraldehyde $\left(x_{3}\right)$. The independent variables contained 3 equidistant levels $\left(4,8\right.$, and $12 \mathrm{mg} / \mathrm{mL}$ for $x_{1} ; 1.5,2.0$, and $2.5 \mathrm{~g} /$ $100 \mathrm{~mL}$ for $x_{2}$; and $0.2,0.4$, and $0.6 \mathrm{~g} / 100 \mathrm{~mL}$ for $x_{3}$ ), which were coded (parenthetical values) as $-1,0$, and 1 .

RSM Experimental Design. An RSM experiment was conducted using Minitab 16 software (Minitab Inc., State College, PA). A Box-Behnken design was used to optimize the process parameters. The design involved 15 runs with 3 independent variables in 1 block (Van der Ven et al., 2002). The independent variables included the concentrations of proteinase $\left(x_{1}\right)$, sodium alginate $\left(x_{2}\right)$, and glutaraldehyde $\left(x_{3}\right)$. The independent variables contained 3 equidistant levels $(4,8$, and 12 $\mathrm{mg} / \mathrm{mL}$ for $x_{1} ; 1.5,2.0$, and $2.5 \mathrm{~g} / 100 \mathrm{~mL}$ for $x_{2}$; and $0.2,0.4$, and $0.6 \mathrm{~g} / 100 \mathrm{~mL}$ for $x_{3}$ ), which were coded as $-1,0$, and +1 (Table 1 ).

The average of the immobilized proteinase activity (all experiments were performed 3 times) was selected as the response $(y)$. The system was explained by the polynomial equation

$$
y=\beta_{0}+\sum_{i=1}^{3} \beta_{i} x_{i}+\sum_{i=1}^{3} \beta_{i i} x_{i}^{2}+\sum_{i=1}^{2} \sum_{j=i+1}^{3} \beta_{i j} x_{i} x_{j},
$$

where $y$ is the dependent variable, and $\beta_{0}, \beta_{i}, \beta_{i i}$, and $\beta_{i j}$ are coefficients estimated by the model; $\beta_{0}, \beta_{i}, \beta_{i i}$, and $\beta_{i j}$ represent, respectively, the constant, linear, quadratic, and cross effects of the factors $\left(x_{1}, x_{2}\right.$, and $\left.x_{3}\right)$ on the response (y) (Pan and Guo, 2010).

\section{Characteristics of Free and Immobilized Proteinases}

Effect of $p H$ and Temperature on Free and Immobilized Proteinases. The free and immobilized proteinases were incubated in $50 \mathrm{~m} M$ Tris- $\mathrm{HCl}$ buffer
$(\mathrm{pH} 5.0-9.0)$ at $37^{\circ} \mathrm{C}$, and the activity of the proteinases was assayed according to the method described below. The free and immobilized proteinases were also incubated at different temperatures ranging from $29^{\circ} \mathrm{C}$ to $49^{\circ} \mathrm{C}$ in $50 \mathrm{mM}$ Tris- $\mathrm{HCl}$ buffer (pH 7.0) and activity was assayed according to the method described below.

$p H$ and Thermo Stability of Free and Immobilized Proteinases. The free and immobilized proteinases were incubated at different $\mathrm{pH}$ values (3.0, $4.0,5.0,6.0,7.0,8.0$, and 9.0) for $30 \mathrm{~min}$ to measure $\mathrm{pH}$ stability. The free and immobilized proteinases were incubated between $30^{\circ} \mathrm{C}$ and $90^{\circ} \mathrm{C}\left(10^{\circ} \mathrm{C}\right.$ increments) for $30 \mathrm{~min}$ in a water bath to measure thermo stability. The residual activity was determined under standard conditions according to the method described below.

Storage Stability and Reusability of Immobilized Proteinases. To evaluate their storage stability, the immobilized proteinases were stored at $4^{\circ} \mathrm{C}$ for 30 $\mathrm{d}$; their activity was measured at 3,7 , and $30 \mathrm{~d}$. The immobilized proteinases were analyzed for their reusability by recycling 5 times. The alginate beads were separated from substrate solution by filtration and washed with Tris-HCl buffer (50 $\mathrm{m} M, \mathrm{pH} 7.0)$ after each proteinase activity measurement. Then, the next activity measurement was carried out and the first-run activity was defined as 100\% (Zhou et al., 2010).

\section{Measuring Activity of Free and Immobilized Proteinases}

One milliliter of free proteinase $(0.1 \mathrm{~g} / \mathrm{mL})$ or $1 \mathrm{~g}$ of immobilized proteinase and $0.05 \mathrm{~mL}$ of $6.4 \mathrm{mM}$ substrate 
methoxy-succinyl-arginyl-prolyl-tyrosyl-p-nitroanilide (MeOsuc-Arg-Pro-Tyr-pNA; MP Biomedicals, Solon, $\mathrm{OH})$ dissolved in methanol were added to $2.85 \mathrm{~mL}$ of $50 \mathrm{~m} M$ Tris- $\mathrm{HCl}$ buffer $(\mathrm{pH} 7.0$ ), and the mixtures were incubated at $37^{\circ} \mathrm{C}$ for $60 \mathrm{~min}$. Then, $0.5 \mathrm{~mL}$ of $30 \%$ (vol/vol) acetic acid was added to the mixtures to stop the reactions. The absorbance (A) of the liberated paranitroaniline was measured at $410 \mathrm{~nm}$. Proteinase activity (U) of proteinase activity was defined as the amount of enzyme that produced an increase of 0.01 unit of $\mathrm{A}_{410 \mathrm{~nm}}$ per hour at $37^{\circ} \mathrm{C}$ :

Specific immobilized proteinase activity

$(\mathrm{U} / \mathrm{mg})=$ immobilized proteinase activity $(\mathrm{U}) /$

weight of free proteinases $(\mathrm{mg})$ contained

in $1 \mathrm{~g}$ of immobilized proteinase.

\section{Production of Whey Hydrolysates}

Whey protein concentrate (WPC)-80 (Beijing Milky Way Trade Corp., Beijing, China) had the following composition: whey protein $(80 \%)$, fat $(6 \%)$, moisture $(5 \%)$, lactose $(4.7 \%)$, and minerals $(2.8 \%)$. An aqueous WPC-80 solution ( $5 \% \mathrm{wt} / \mathrm{vol}$, protein basis) was heated at $65^{\circ} \mathrm{C}$ for $20 \mathrm{~min}$ and then cooled to room temperature. Immobilized proteinase of L. helveticus LB 10 was added to the WPC-80 solution at a final concentration of $15 \%$ (wt/vol) and incubated at $37^{\circ} \mathrm{C}$ for $12 \mathrm{~h}$. To observe production of ACE-inhibitory peptides in the process of fermentation for $12 \mathrm{~h}, 1-\mathrm{mL}$ aliquots were taken at 1-h intervals over $12 \mathrm{~h}$ and centrifuged at $7,000 \times g$ for $10 \mathrm{~min}$ to remove immobilized proteinases, which were washed with sterilized water for reuse. The supernatant, composed of crude ACE-inhibitory peptides, was adjusted to $\mathrm{pH} 3.8$ with $50 \%$ lactic acid solution (Pan and Guo, 2010). After centrifugation at $7,000 \times g$ for $10 \mathrm{~min}$, the supernatant was collected and the $\mathrm{pH}$ was readjusted to 7.0. Then, the ACEinhibitory activity of the supernatant was measured. The whey hydrolysate supernatant was collected after at $8 \mathrm{~h}$ of centrifugation $(7,000 \times g, 10 \mathrm{~min})$. The peptide concentration of the supernatant was analyzed and the supernatant freeze-dried for further use. Peptide concentration was determined according to the biuret reaction test (Pan et al., 2011).

\section{Fractionation of Whey Hydrolysates by Gel Filtration}

Whey hydrolysates were applied to a Sephadex G-15 column $(1.0 \times 40 \mathrm{~cm}$, Amersham Pharmacia Biotech, Uppsala, Sweden) equilibrated with distilled water.
Peptides were eluted with distilled water at a flow rate of $25 \mathrm{~mL} / \mathrm{h}$. Elution curves were obtained by measuring absorbance at $220 \mathrm{~nm}$. The fractions were collected at 5-min intervals. The experiments were conducted at room temperature using MA99-2A Protein Chromatography Equipment (Shanghai Huxi Analysis Instrument Factory, Shanghai, China). All fractions under each peak were pooled separately and concentrated by freeze-drying; then, their ACE-inhibitory activity was determined. The fraction with the highest ACE-inhibitory activity was then applied to a Sephadex G-10 column $(1.0 \times 40 \mathrm{~cm}$, Amersham Pharmacia Biotech $)$ equilibrated with distilled water. Peptides were eluted under the same conditions as for the Sephadex G-15 column. The fractions were pooled, concentrated by freeze-drying, and assayed for ACE-inhibitory activity.

\section{Transport of Peptide Mixtures Across the Caco-2 Cell Monolayer}

Establishment of Caco-2 Cell Monolayer Model. Caco-2 cells (Shanghai Institute of Cell Biology, Shanghai, China) were cultured in Dulbecco's modified Eagle's medium (Gibco Life Technologies, Grand Island, NY) supplemented with 10\% fetal bovine serum (Gibco Life Technologies) and $1 \%$ penicillinstreptomycin solution in an incubator with a $5 \% \mathrm{CO}_{2}$ atmosphere at $37^{\circ} \mathrm{C}$. The Caco- 2 cell monolayer was incubated in Transwell Permeable Supports $\left(1.12 \mathrm{~cm}^{2}\right.$, $0.4-\mu \mathrm{m}$ pore size) (Corning Costar, Cambridge, MA) at $2 \times 10^{5}$ cells $/ \mathrm{cm}^{2}$. The medium was changed every day until a monolayer formed and then the monolayer was allowed to grow for $21 \mathrm{~d}$ until it took shape. The integrity of the monolayer was observed using a JEM1400 electron microscope (JEOL, Tokyo, Japan) and was also evaluated by measuring the transepithelial electrical resistance (TEER) using a Millicell ERS-2 V ohm meter (Millipore, Bedford, MA; Srinivasan et al., 2015). Lucifer yellow and alkaline phosphatase activity were analyzed and used to measure the integrity and differentiation of the monolayer (Mineo et al., 2002; Dihal et al., 2006).

Peptide Transport Across the Caco-2 Cell Monolayer. The Transwell inserts were incubated with Hanks' balanced salt solution (HBSS) buffer ( $\mathrm{pH}$ 7.4) at $37^{\circ} \mathrm{C}$ for $30 \mathrm{~min}$. The peptide fraction from the Sephadex G-10 column separation in $0.5 \mathrm{~mL}$ of HBSS buffer ( $\mathrm{pH} 7.4$ ) at a concentration of $1 \mathrm{mg} / \mathrm{mL}$ was added to the apical chamber. An aliquot of $1.5 \mathrm{~mL}$ of HBSS buffer ( $\mathrm{pH} 7.4$ ) was added to the basolateral (BL) side of each well. The same volume of HBSS buffer ( $\mathrm{pH}$ 7.4) without sample (blank control) was added to the apical and BL sides. After $1 \mathrm{~h}$ of incubation, BL 
solutions were collected and analyzed using UPLC-MS/ MS.

\section{Identification of ACE-Inhibitory Peptides Using UPLC-MS/MS Analysis}

Samples before and after transport were analyzed using a Waters MALDI (matrix-assisted laser desorption/ ionization) Synapt Q-TOF (quadrupole-time-of-flight) MS (Waters, Milford, MA). The UPLC was performed on a Waters Acquity UPLC system with an Acquity UPLC BEH 130 C18 column $(2.1 \times 150 \mathrm{~mm}, 1.7 \mu \mathrm{m}$; Waters). An $8-\mu \mathrm{L}$ aliquot of sample was injected. Elution was performed with solvent A ( $100 \%$ acetonitrile) and $\mathrm{B}\left(0.1 \%\right.$ methanoic acid in $\left.\mathrm{H}_{2} \mathrm{O}\right)$. Peptides were eluted with a linear gradient of solvent A from 2 to $40 \%$ in $10 \mathrm{~min}$, to $100 \%$ in $17 \mathrm{~min}$, and to $2 \%$ in the next 5 min, and solvent B from 98 to $60 \%$ in $10 \mathrm{~min}$, to $0 \%$ in $17 \mathrm{~min}$, and to $98 \%$ in the next $5 \mathrm{~min}$. The flow rate was $0.3 \mathrm{~mL} / \mathrm{min}$.

The ion source was ESI+, the capillary and cone voltages were $3.5 \mathrm{kV}$ and $30 \mathrm{~V}$, respectively, and the source block temperature was $100^{\circ} \mathrm{C}$. The desolvation temperature was $300^{\circ} \mathrm{C}$, and the desolvation and cone gas flows were 500 and $50 \mathrm{~L} / \mathrm{h}$, respectively. The low collision energy was $6 \mathrm{~V}$ and high collision energy was $35 \mathrm{~V}$. Low collision energy was used to measure peptide accurate mass and intensity (abundance) and high collision energy was used to generate MS/MS spectra and identify peptide fragments (Foltz et al., 2015). The mass-to-charge range was 100 to $1,500 \mathrm{~m} / z$. The detector voltage was 1,600 to $1,700 \mathrm{~V}$.

MassLynx v4.1 (Waters) and GPMAW 8.0 (GPMAW, Odense, Denmark) software were used to identify the peptide sequences. Detected peptides were compared against fragments of known whey proteins including $\beta$-LG, $\alpha$-LA, glycomacropeptide, immunoglobulins, BSA, lactoferrin, and lactoperoxidase using the National Center for Biotechnology Information (NCBI) database (https://www.ncbi.nlm.nih.gov/). The peptides detected by UPLC-MS/MS, KA, EN, DIS, EVD, LF, AIV, and VFK, from the BL side of the Caco-2 cell model were synthesized at $\geq 90 \%$ purity by Shanghai Peptide Co. (Shanghai, China), and their ACE-inhibitory activity was measured.

\section{Measurement of ACE-Inhibitory Activity}

A $100-\mu \mathrm{L}$ sample of peptides at different concentrations $(0.05,0.5,1,2,3$ and $4 \mathrm{~m} M)$ was mixed with 200 $\mu \mathrm{L}$ of hippuryl-L-histidyl-L-leucine (HHL) substrate solution (6.7 mM, pH 8.3; Sigma, St. Louis, MO) and incubated at $37^{\circ} \mathrm{C}$ for $5 \mathrm{~min}$. Then, ACE from rab- bit lung (30 $\mu \mathrm{L}, 0.33 \mathrm{U} / \mathrm{mL}$; Sigma) was added to the mixture and incubated for $30 \mathrm{~min}$ at $37^{\circ} \mathrm{C}$. The ACE-inhibitory activity was measured according to the method described by Cushman and Cheung (1971), according to the following equation:

$$
\begin{gathered}
\text { ACE-inhibitory activity }(\%)= \\
100 \% \times[(A-B)-(C-D)] /(A-B),
\end{gathered}
$$

where $A$ is the absorbance of the solution containing ACE without the peptide sample, $B$ is the absorbance of the solution with ACE before inactivation by adding $\mathrm{HCl}$ without the sample, $C$ is the absorbance in the presence of $\mathrm{ACE}$ and sample, and $D$ is the absorbance in the presence of $\mathrm{ACE}$ and the sample, with $\mathrm{ACE}$ measured before inactivation by $\mathrm{HCl}$ (Toopcham et al., 2015).

The half-maximal inhibitory concentration $\left(\mathbf{I C}_{\mathbf{5 0}}\right)$ was defined as the concentration of inhibitor required to inhibit $50 \%$ of the ACE activity under the assay conditions. The $\mathrm{IC}_{50}$ was calculated by Probit analysis using IBM Statistical Package for the Social Sciences (SPSS) Statistics 20 software (IBM Corp., Armonk, NY).

\section{Measurement of Protein Concentration}

The protein concentration of proteinase was determined according to the Bradford assay using BSA as a standard (Bradford, 1976).

\section{Statistical Analyses}

All analyses were conducted in triplicate and the results were expressed as mean values \pm standard deviations. Analysis of variance was used to quantify significant differences between levels. Significant differences were determined by one-way ANOVA followed by a Tukey honestly significant difference (HSD) test for multiple comparisons. A probability value of $P<$ 0.05 was recognized as statistically significant. Statistical analyses were performed using a Minitab 16 system (Minitab Inc.).

\section{RESULTS AND DISCUSSION}

\section{Immobilization of Proteinases}

Figure 1A shows the activity of the immobilized proteinases at different concentrations of sodium alginate. Increasing the sodium alginate concentration increased the thickness of the alginate-bead membrane. Substrate 
has difficulty diffusing through alginate beads at high concentrations of sodium alginate (Idris and Suzana, 2006). We found that beads of $2.0 \mathrm{~g} / 100 \mathrm{~mL}$ of sodium alginate were hard enough and were optimal, because they provided the highest level of immobilized proteinase activity. Therefore, $2.0 \mathrm{~g} / 100 \mathrm{~mL}$ was chosen as the center point of the RSM, with $0.5 \mathrm{~g} / 100 \mathrm{~mL}$ as the step change (Table 1). Calcium chloride is used as a cross linking agent, and its concentration is directly related to bead intensity and stability (Ganaie et al., 2014). Concentrations of $\mathrm{CaCl}_{2}$ of $0.1 \mathrm{~mol} / \mathrm{L}$ (Ganaie et al., 2014) and $0.2 \mathrm{~mol} / \mathrm{L}$ (Nawaz et al., 2015) were reported to perform well for cross linkage of enzymeentrapped beads. Concentrations of $\mathrm{CaCl}_{2}$ in the range of 0.05 to $0.25 \mathrm{~mol} / \mathrm{L}$ were chosen to study the effects on activity of the immobilized proteinases in the current study. As can be seen in Figure 1B, we observed no significant difference in the activity of immobilized proteinases at different $\mathrm{CaCl}_{2}$ concentrations from 0.05 to $0.25 \mathrm{~mol} / \mathrm{L}$. This is consistent with a previous report that a $\mathrm{CaCl}_{2}$ concentration of 0.05 to $0.2 \mathrm{~mol} / \mathrm{L}$ had slight effects on immobilized lipase yield and activity (Jeamjounkhaw et al., 2007). Therefore, $\mathrm{CaCl}_{2}$ was not chosen as a center point of the RSM. Figure $1 \mathrm{C}$ shows the activity of immobilized proteinases at different glutaraldehyde concentrations (0.2 to $1.0 \%$ ). Activity increased with glutaraldehyde concentrations from 0.2 to $0.4 \%$ and then decreased from 0.4 to $1.0 \%$. Therefore, $0.4 \%$ was chosen as the center point with $0.2 \%$ as the step change (Table 1). Figure 1D shows the activity of immobilized proteinases at different proteinase concentrations (4 to $20 \mathrm{mg} / \mathrm{mL}$ ); activity increased from 4 to $8 \mathrm{mg} / \mathrm{mL}$ and then decreased from 8 to 20 $\mathrm{mg} / \mathrm{mL}$. Therefore, $8 \mathrm{mg} / \mathrm{mL}$ was chosen as the center point with $4 \mathrm{mg} / \mathrm{mL}$ as the step change (Table 1). From this experiment, the sodium alginate, glutaraldehyde and proteinase concentrations were chosen as factors for the RSM experiment. Alginate has been widely used to immobilize many enzymes via entrapment (Pal and Khanum, 2011). Alginate is composed of $\alpha$-L-guluronic and $\beta$-D-mannuronic acid. Proteinases can be embedded in alginate beads with cross-linking between $\alpha-\mathrm{L}^{-}$ guluronic acid and calcium ions (Zhou et al., 2010). As a hardening agent, glutaraldehyde was used to increase the rigidity and mechanical strength of immobilized enzymes (Zhou et al., 2010). Pal and Khanum (2011) reported that an enzyme attached to the surface of alginate beads through glutaraldehyde could enhance the accessibility of substrates to the enzyme trapped in the beads and improve the outward diffusion efficiency of hydrolytic products.

Table 1 shows the design and results of the RSM experiment, and Tables 2 and 3 show the statistical analysis of results. The effect of each factor on specific immobilized proteinase activity was identified by their $t$-test and $P$-values. Factors $x_{1}$ (proteinase concentration), $x_{2}$ (sodium alginate concentration), and $x_{3}$ (glutaraldehyde concentration) had significant effects $(P<0.05)$ on specific immobilized proteinase activity (Tables 2 and 3). The square terms $x_{1} \times x_{1}, x_{2} \times x_{2}$, and $x_{3} \times x_{3}$ also had significant effects $(P<0.05)$ on specific immobilized proteinase activity (Tables 2 and 3 ). Equation [4] shows the specific immobilized proteinase activity in relation to the 3 factors. Multiple regression analysis of the experimental data was used to obtain the parameters of the equation. The experimental data were explained by the following quadratic model:

$$
\begin{aligned}
y & =-18.4133+0.9780 \times x_{1}+14.7033 \times x_{2}+19.1729 \times x_{3} \\
& +0.0712 \times x_{1} \times x_{2}-0.0562 \times x_{1} \times x_{3}+1.6250 \times x_{2} \times x_{3} \\
& -0.0729 \times x_{1}^{2}-3.9133 \times x_{2}^{2}-28.1458 \times x_{3}^{2},
\end{aligned}
$$

where $y$ was the predicted response, and $x_{1}, x_{2}$, and $x_{3}$ were the uncoded values of the variable proteinase, sodium alginate and glutaraldehyde concentrations, respectively.

The adjusted coefficient of determination $\left(\mathrm{R}^{2}\right.$-adj) was used to check the fit of the model (Eq. [4]). A high $\mathrm{R}^{2}$-adj value indicated that the model was well adapted to the response. The $\mathrm{R}^{2}$-adj was 0.946 , which indicated that $94.6 \%$ of the variability in the response in relation to the activity of the specific immobilized proteinases could be explained by the model (Table 2). Table 3 shows a nonsignificant $(P>0.05)$ lack of fit, which indicates that the proposed model (Eq. [4]) fits well. The response (specific immobilized proteinase activity) on the z-axis against any 2 independent variables was plotted, whereas the other variables were maintained at their optimal levels. Therefore, 3-dimensional response surface plots were constructed (Figure 1E, 1F, and $1 G)$. The activity of specific immobilized proteinases increased until the proteinase, sodium alginate, and glutaraldehyde concentrations reached an optimum point and then decreased as the concentrations increased. The optimal conditions of the variables were a proteinase concentration of $7.55 \mathrm{mg} / \mathrm{mL}$, a sodium alginate concentration of $2.03 \mathrm{~g} / 100 \mathrm{~mL}$, and a glutaraldehyde concentration of $0.39 \%$. The predicted activity of specific immobilized proteinases was $3.95 \mathrm{U} / \mathrm{mg}$ under these conditions. An experiment was run 3 times under the optimal conditions, and the activity was 3.80 $\pm 0.16 \mathrm{U} / \mathrm{mg}$. Thus, we confirmed that the conditions analyzed by Minitab 16 (Minitab Inc.) were optimal to immobilize the proteinases. We found that RSM was an 
A

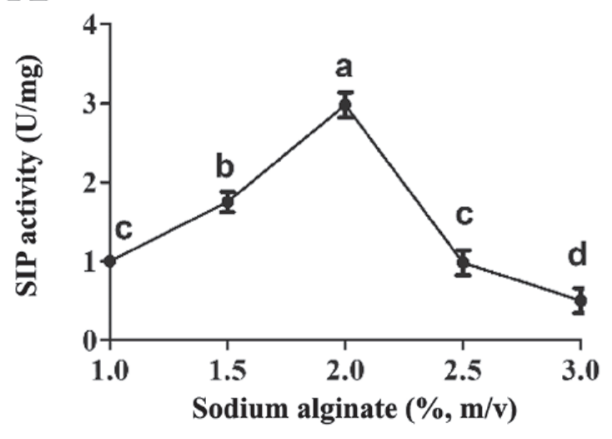

C

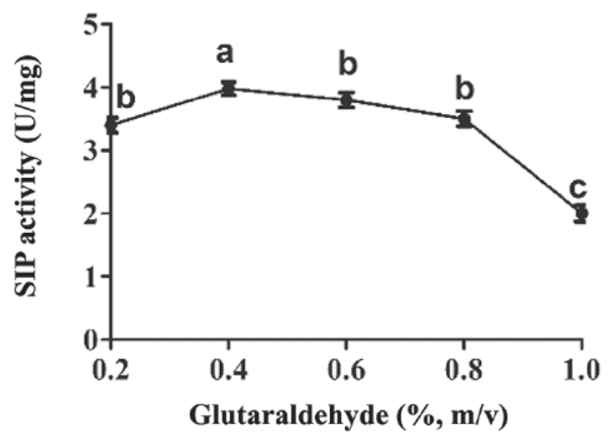

$\mathbf{E}$

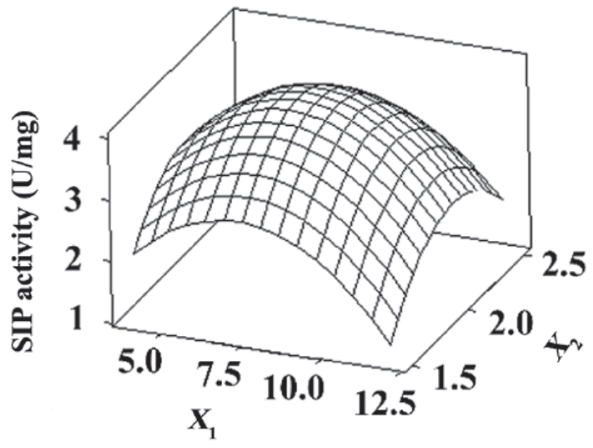

G

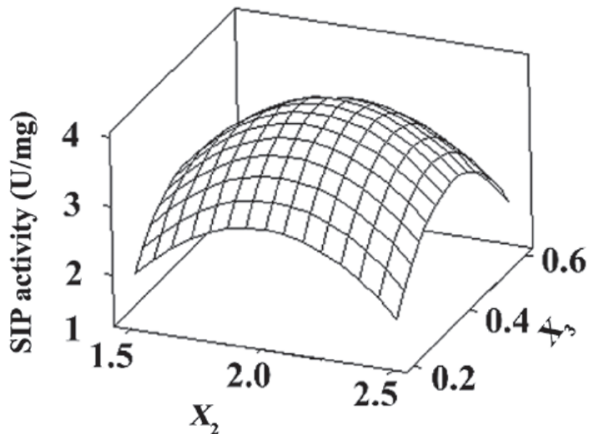

B

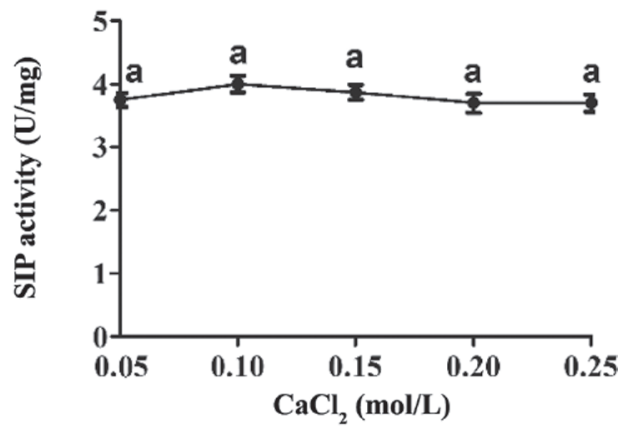

D

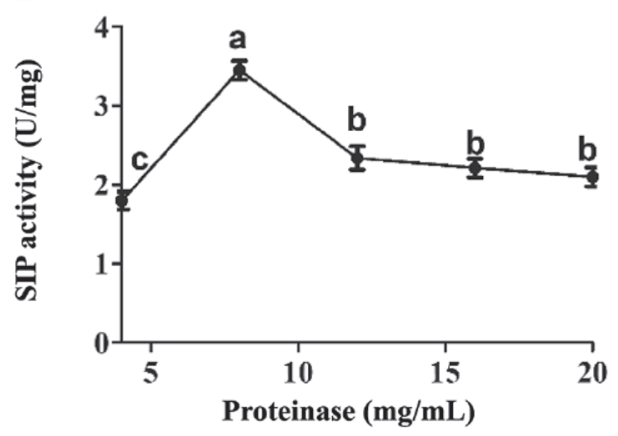

$\mathbf{F}$

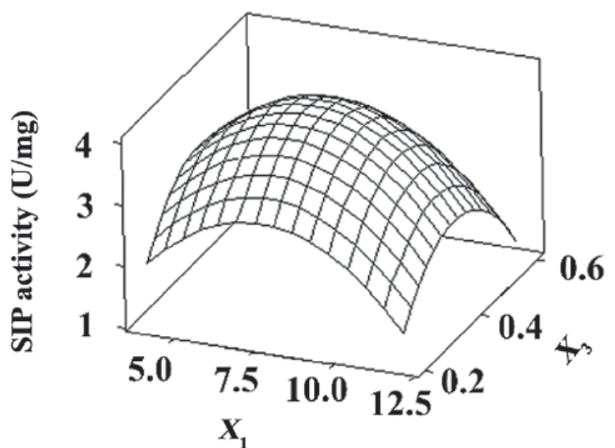

Figure 1. Effect of sodium alginate (A; \% mass/volume), calcium chloride (B; mol/L), glutaraldehyde (C; \% mass/volume), and proteinase $(\mathrm{D} ; \mathrm{mg} / \mathrm{mL})$ concentrations on specific immobilized proteinase (SIP) activity. Data are the mean $\pm \mathrm{SE}(\mathrm{n}=3)$ of at least 3 independent experiments. Response surface plots for the effect of variables on SIP activity: (E) proteinase $\left(x_{1}\right)$ and sodium alginate $\left(x_{2}\right)$ concentrations; $(\mathrm{F})$ proteinase $\left(x_{1}\right)$ and glutaraldehyde $\left(x_{3}\right)$ concentrations; $(\mathrm{G})$ sodium alginate $\left(x_{2}\right)$ and glutaraldehyde $\left(x_{3}\right)$ concentrations. Different letters indicate significant differences among groups $(P<0.05)$. 
Table 2. Estimated uncoded regression coefficients for specific immobilized proteinase activity (U/mg)

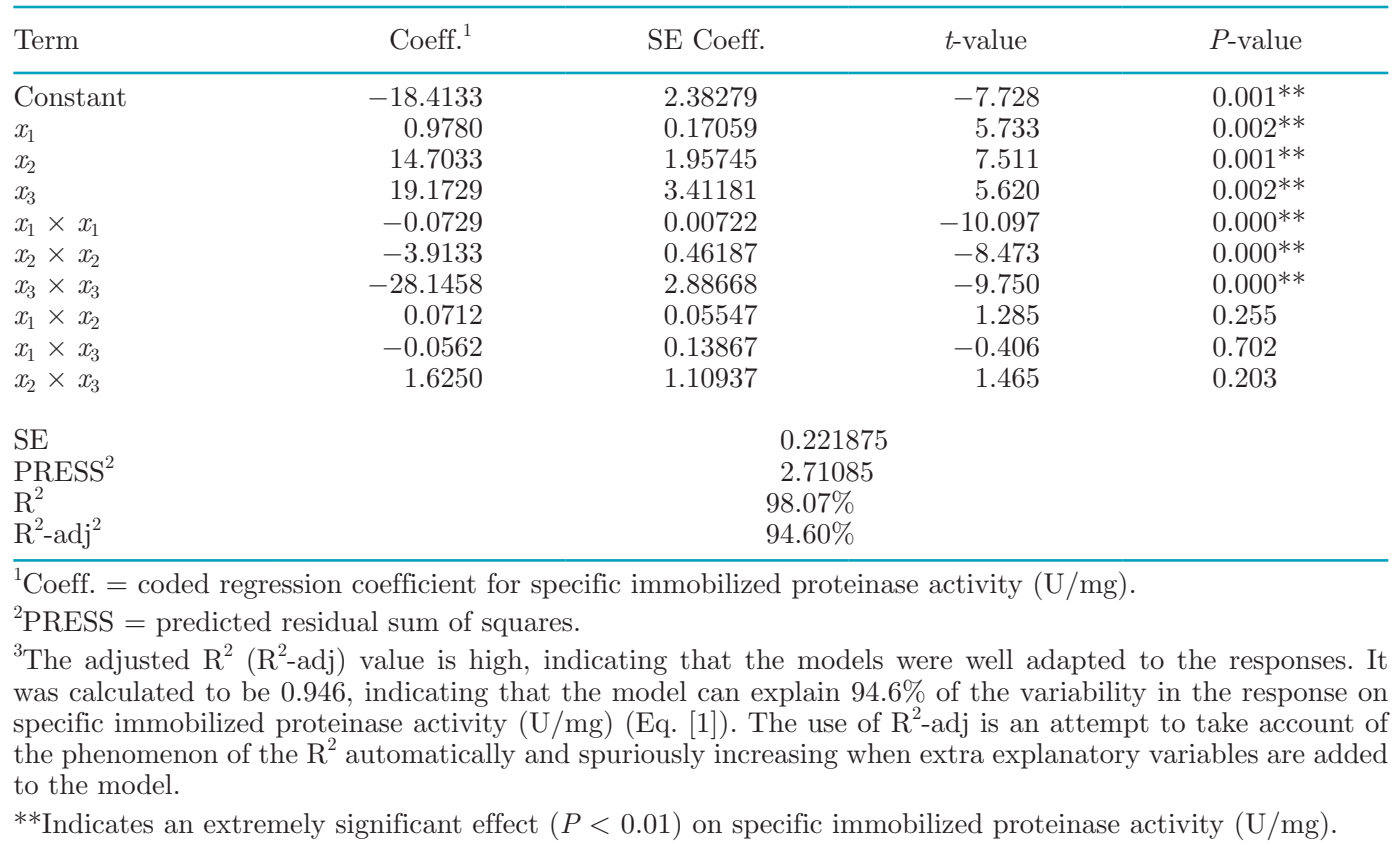

efficient statistical tool to optimize the immobilization conditions for the proteinases.

\section{Characteristics of Immobilized Proteinases of L. helveticus LB10}

Effect of $p H$ and Temperature. Enzymes have ionic groups on their active sites and these ionic groups must be in a suitable form to function. Changes in $\mathrm{pH}$ affect the ionic form of the active site and change the activity of the enzyme (Tümtürk et al., 2007). In our study, the activity of the free and immobilized proteinases exhibited maximal activity at $\mathrm{pH} 7.0$ (Figure 2A). A similar observation has been made in other studies, in which immobilization of an enzyme did not change its optimum pH (Nawaz et al., 2015). The optimum temperatures for free and immobilized proteinases were $37^{\circ} \mathrm{C}$ and $41^{\circ} \mathrm{C}$, respectively (Figure 2B). Some researchers have reported that the optimal temperature of the immobilized enzyme shifted to a higher value than that of the free enzyme (Tümtürk et al., 2007). Immobilized enzymes have the potential to change the microenvironment surrounding enzyme molecules, thereby improving the stability of the enzyme (Zhao et al., 2017).

$p H$ and Thermo Stability. The immobilized proteinases displayed good $\mathrm{pH}$ and thermo stability. Immobilized proteinases retained more than $60 \%$ of their activity, whereas the free enzyme retained only $10 \%$ at $\mathrm{pH} 9.0$ (Figure 2C). The activities of free and immobilized proteinases were stable up to $50^{\circ} \mathrm{C}$ (Figure $2 \mathrm{D})$. When heated to $60^{\circ} \mathrm{C}$, the immobilized protein-

Table 3. Analysis of variance for specific immobilized proteinase activity $(\mathrm{U} / \mathrm{mg})$

\begin{tabular}{lccccc}
\hline Source & df & $\begin{array}{c}\text { Sequential sums } \\
\text { of squares }\end{array}$ & $\begin{array}{c}\text { Adjusted sums } \\
\text { of squares }\end{array}$ & $\begin{array}{c}\text { Adjusted } \\
\text { mean square }\end{array}$ & $F$-value \\
\hline Regression & 9 & 12.5078 & 12.5078 & 1.38975 & 28.23 \\
Linear & 3 & 0.8290 & 4.4106 & 1.47021 & 29.87 \\
Square & 3 & 11.4838 & 11.4838 & 3.82793 & 77.76 \\
Interaction & 3 & 0.1949 & 0.1949 & 0.06498 & $0.001^{* *}$ \\
Residual error & 5 & 0.2461 & 0.2461 & $0.000^{* *}$ \\
Lack of fit $^{1}$ & 3 & 0.1569 & 0.1569 & 0.04923 & 0.203 \\
Pure error & 2 & 0.0893 & 0.0893 & 0.04463 & 0.491 \\
Total & 14 & 12.7539 & & & \\
\end{tabular}

${ }^{1}$ The $P$-value of 0.491 indicates a nonsignificant $(P>0.05)$ lack of fit, which further validates the model.

**Indicates an extremely significant effect $(P<0.01)$ on specific immobilized proteinase activity $(\mathrm{U} / \mathrm{mg})$. 
-Immobilized enzyme

-Free enzyme
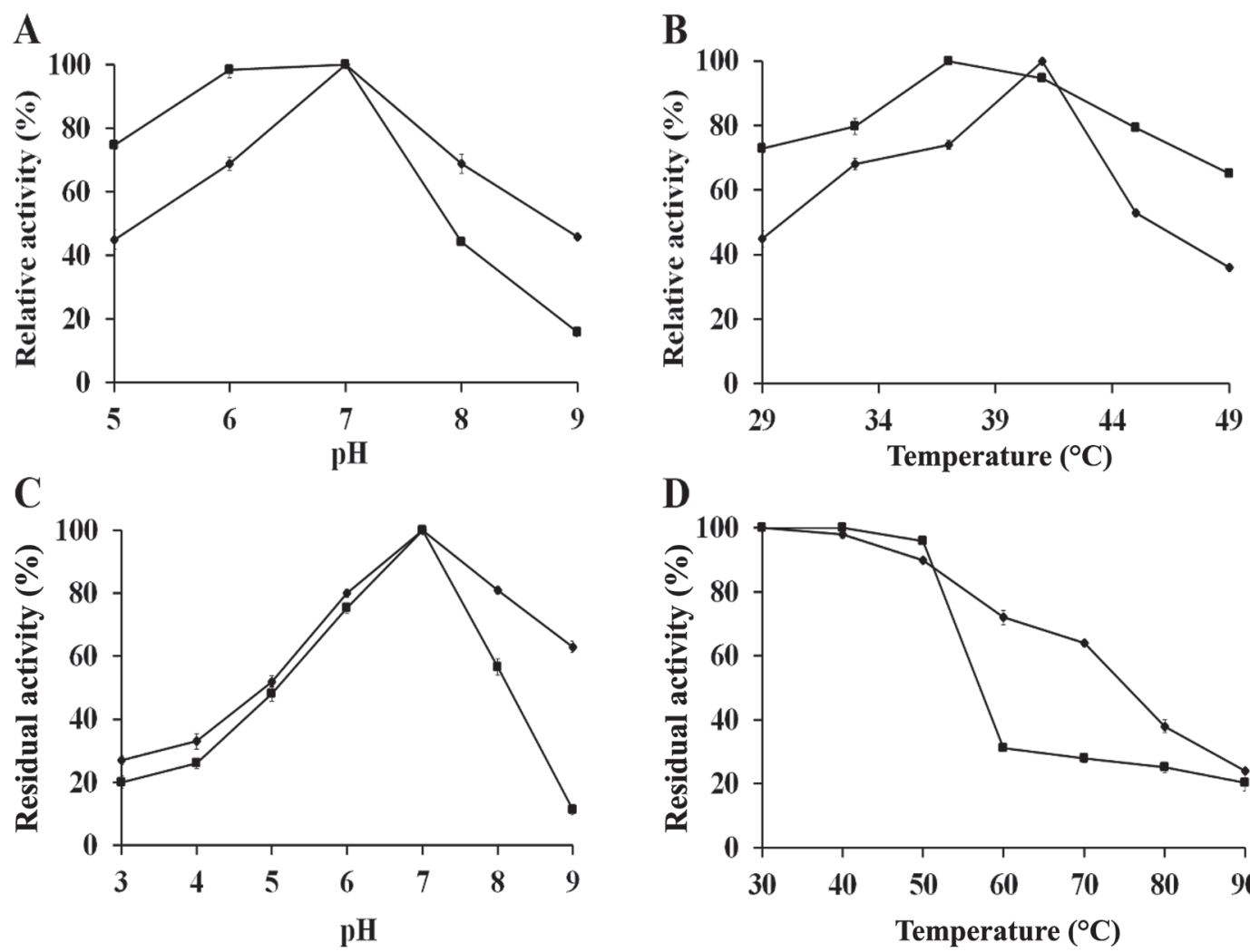

D
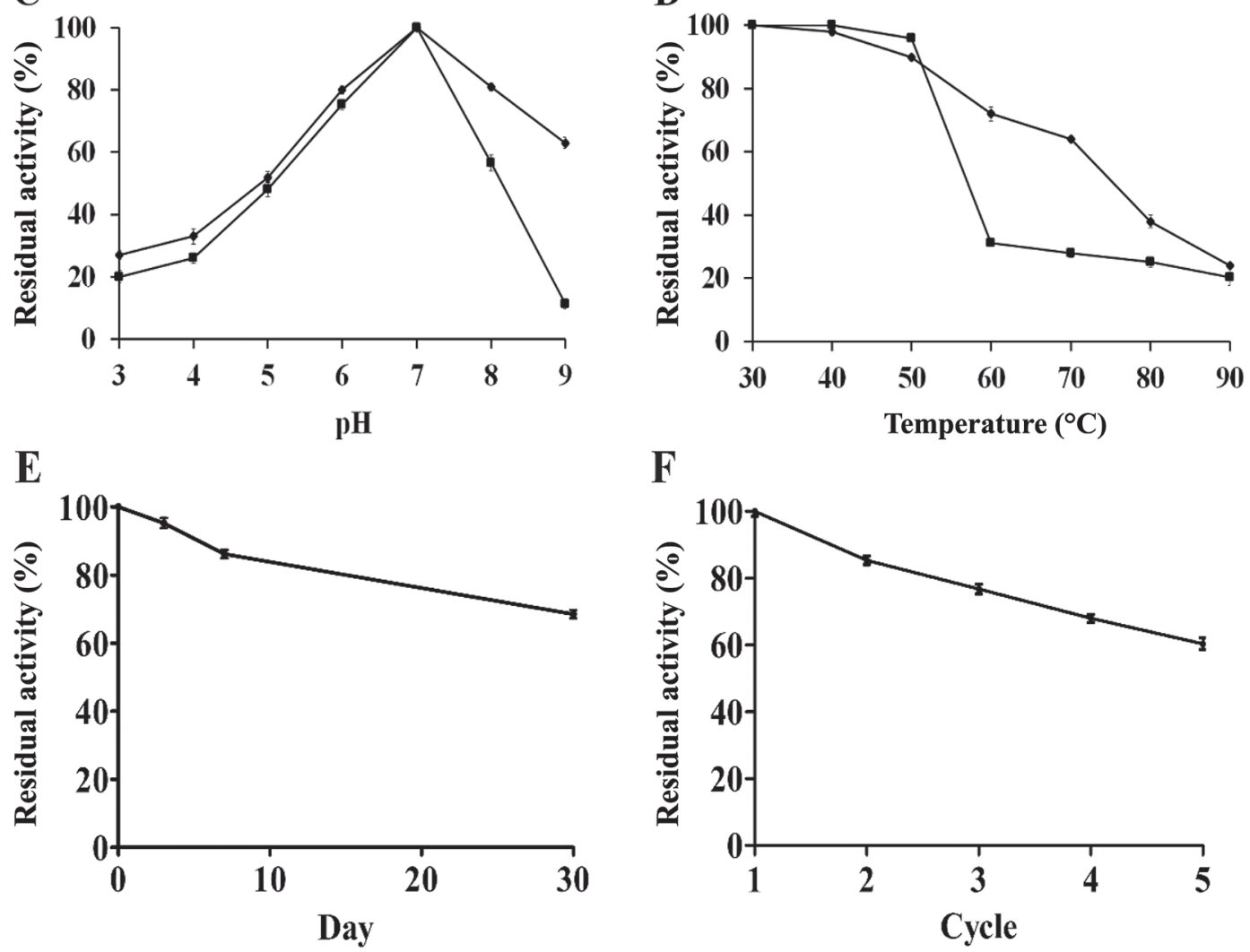

Figure 2. Effect of (A) pH and (B) temperature on free and immobilized proteinase activity; (C) pH (C) and thermal (D) stability of free and immobilized proteinases; (D) Thermo stability of the free and immobilized proteinases; storage stability (E) of immobilized proteinases over $30 \mathrm{~d}$; and $(\mathrm{F})$ reusability of immobilized proteinases for 5 cycles. Data are the mean $\pm \mathrm{SE}(\mathrm{n}=3)$ of at least 3 independent experiments.

ases retained $70 \%$ of their control activity, whereas free enzyme activity was only $30 \%$. The greater stability of the immobilized proteinases in relation to $\mathrm{pH}$ and heating may be related to covalent linkages and secondary interactions (e.g., ionic and polar stabilization, hydrogen bonding) between the enzyme and the matrix (LeTien et al., 2004).
Storage Stability and Reusability. Storage stability is one of the key factors that affects the evaluation and selection for use of any industrially important enzyme (Kumar et al., 2017). The storage stability of the immobilized proteinases in this study was high. The residual activity was $95.3,86.2$, and $68.5 \%$ after 3,7 , and $30 \mathrm{~d}$, respectively (Figure $2 \mathrm{E}$ ). The residual 
activity of the immobilized proteinases was $60.4 \%$ of the original activity after 5 cycles (Figure 2F). The improved storage stability and reusability could be due to strong covalent linkage between the enzyme and matrix or structural rigidity (Pal and Khanum, 2011; Kumar et al., 2017).

\section{Production and Purification of Whey Hydrolysates}

Whey was hydrolyzed into mixtures of peptides by using immobilized proteinases of $L$. helveticus as a catalytic agent. As shown in Figure 3A, the ACE-inhibitory activity of the hydrolysate increased from 2 to $8 \mathrm{~h}$. After $8 \mathrm{~h}$, the ACE-inhibitory activity of the hydrolysate decreased. The same phenomenon was reported by Toopcham et al. (2017), who found that further digestion resulted in a decrease in ACE-inhibitory activity. This might be explained by the substrate being exhausted and peptides with ACE-inhibitory activity being further hydrolyzed and losing their activity (Guo et al., 2009). The whey protein hydrolysate was collected at $8 \mathrm{~h}$ and showed ACE-inhibitory activity of $43.00 \pm 1.50 \%$; the peptide concentration was $1.80 \pm$ $0.11 \mathrm{mg} / \mathrm{mL}$.

The hydrolysate was separated using Sephadex G-15 gel filtration chromatography with an exclusion limit of 1,500 Da and 2 fractions were obtained (Figure 3B). High-molecular-weight substances, which are excluded from the gel, are eluted first. The ACE-inhibitory activity of fractions 1 and 2 was $32.28 \pm 1.32 \%$ and $62.82 \pm 2.21 \%$, respectively. The second fraction, with greater ACE-inhibitory activity, was further separated using Sephadex G-10 gel filtration chromatography with an exclusion limit of $700 \mathrm{Da}$. Only one fraction was obtained, which exhibited ACE-inhibitory activity of $67.80 \pm 1.81 \%$, (Figure 3C).

\section{Identification of ACE-Inhibitory Peptides Transported Across a Caco-2 Cell Monolayer}

Figure 3D and 3E show total ion chromatograms (TIC) of the whey peptide mixtures before and after transport across Caco-2 cell monolayers. The fractions in Figure 3D are complex and it is difficult to analyze the peptide sequences of all fractions. By comparing Figure $3 \mathrm{D}$ and $3 \mathrm{E}$, it can be seen that many of whey protein hydrolysate fractions could not cross the intestinal epithelium. Seven peptides were identified after transport, at retention times of 9.55, 9.93, 11.12, 11.57, $11.75,11.89$, and $12.21 \mathrm{~min}$, and were confirmed as Lys-Ala (KA), Glu-Asn (EN), Asp-Ile-Ser (DIS), GluVal-Asp (EVD), Leu-Phe (LF), Ala-Ile-Val (AIV), and Val-Phe-Lys (VFK) from MS/MS spectrum (Figure 4).
We were not able to identify other peaks because of the low concentration or poor MS/MS spectrum, such as the peak at retention time $1.03 \mathrm{~min}$. The tripeptides DIS, EVD, and VFK correspond to the 44-46, 143-145, and 97-99 fragments of $\beta-\mathrm{LG}$, respectively. The tripeptide AIV corresponds to $\alpha$-LA f(59-61) (Supplemental Table S1; https://doi/org/10.3168/jds.2018-14899). The dipeptides KA, EN, and LF are found in fragments of $\beta-\mathrm{LG}, \alpha-\mathrm{LA}, \operatorname{IgG}$, BSA, lactoferrin, and lactoperoxidase (Supplemental Table S1) and their exact source could not be confirmed.

The $\mathrm{IC}_{50}$ of synthesized peptides KA, EN, DIS, EVD, LF, AIV, and VFK were measured and found to be 1.24 $\pm 0.01,1.43 \pm 0.04,1.59 \pm 0.27,1.32 \pm 0.05,1.60 \pm$ $0.39,2.66 \pm 0.02$, and $1.76 \pm 0.09 \mathrm{mmol} / \mathrm{L}$, respectively (Table 4). In previous reports, the $\mathrm{IC}_{50}$ value of the ACE-inhibitory peptides IPP [ $\beta-\mathrm{CN} \mathrm{f(74-76)]} \mathrm{and} \mathrm{VPP}$ $[\beta-\mathrm{CN} \mathrm{f}(84-86)]$ were 5.0 and $9.0 \mu M$ under measurement conditions of $200 \mu \mathrm{L}$ of $5 \mathrm{mM}$ HHL, $20 \mu \mathrm{L}$ of ACE $(0.1 \mathrm{U} / \mathrm{mL}$ ), and $80 \mu \mathrm{L}$ of peptide sample (Nakamura et al., 1995). Under measurement conditions of $20 \mu \mathrm{L}$ of $12.5 \mathrm{mM} \mathrm{HHL}, 30 \mu \mathrm{L}$ of peptide sample, and $25 \mathrm{mU}$ of $\mathrm{ACE}$ in $2 \mu \mathrm{L}$ of glycerol, the $\mathrm{IC}_{50}$ of VYP $[\beta-\mathrm{CN}$ $\mathrm{f}(59-61)]$ was $288 \mu M$ (Abubakar et al., 1998). The $\mathrm{IC}_{50}$ of ALPM [ $\beta$-LG f(142-145)] was $928 \mu M$ when $75 \mu \mathrm{g}$ or $150 \mu \mathrm{L}$ of peptide sample solution was mixed with borate buffer containing $12.5 \mathrm{mM} \mathrm{HHL}$ and $5 \mathrm{mU}$ of ACE (Murakami et al., 2004). The $\mathrm{IC}_{50}$ of KVLPVPQ [ $\beta$-CN $\mathrm{f}(169-175)]$ was $1,000 \mu M$ under the conditions of 200 $\mu \mathrm{L}$ of $3.8 \mathrm{~m} M \mathrm{HHL}, 20 \mu \mathrm{L}$ of peptide sample, and 2 $\mathrm{mU}$ of ACE (Maeno et al., 1996). It has been reported that ACE prefer an inhibitor containing hydrophobic (aromatic or branched side chains) AA residues and a positively charged AA at the C-terminal (Meisel, 1997; Hernández-Ledesma et al., 2011). The presence of Tyr, Phe, Trp, Pro, Ile, Val, Lys, or Arg at the C-terminal has been reported to contribute to ACE-inhibitory activity (Fu et al., 2016). In the present study, DIS and AIV have Ile and Lys, which are branched side-chain $\mathrm{AA}$, at the C-terminal. The dipeptide LF has Phe, an aromatic AA, at the C-terminal; VFK has Lys, which is a positively charged $\mathrm{AA}$, at the $\mathrm{C}$-terminal; $\mathrm{KA}$ has Ala, which is a hydrophobic AA, at the C-terminal. The other 2 peptides, EN and EVD, do not have any reported specific AA at the C-terminal. The other characteristics may be related to the ACE-inhibitory activity.

The characteristics of 7 detected ACE-inhibitory peptides including molecular weight, grand average of hydropathy (GRAVY), and electrostatic charge of the ACE-inhibitory peptides are listed in Table 4. Size of the peptides could be a critical factor influencing intestinal absorption (Raikos and Dassios, 2014). Long- 

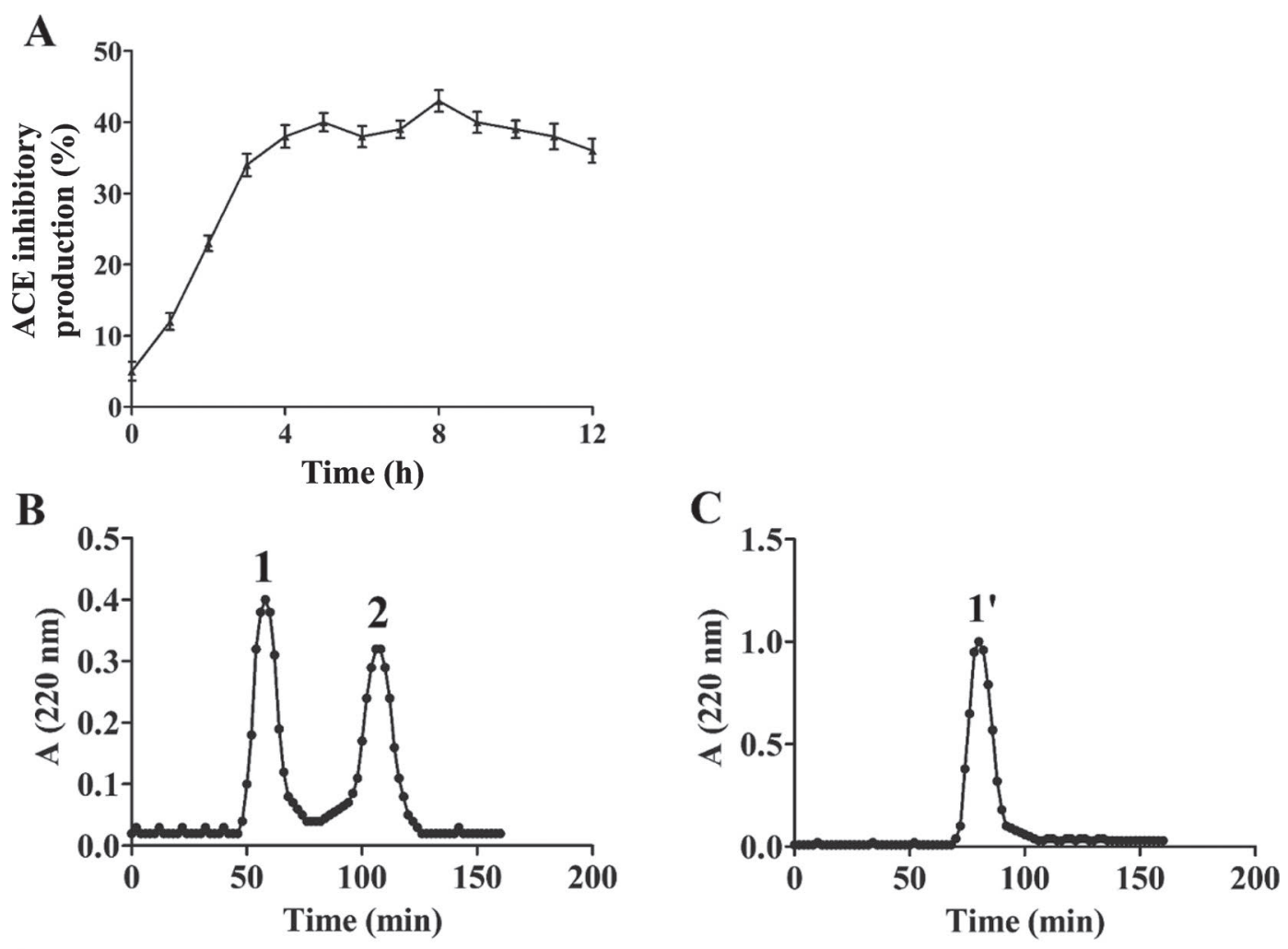

D

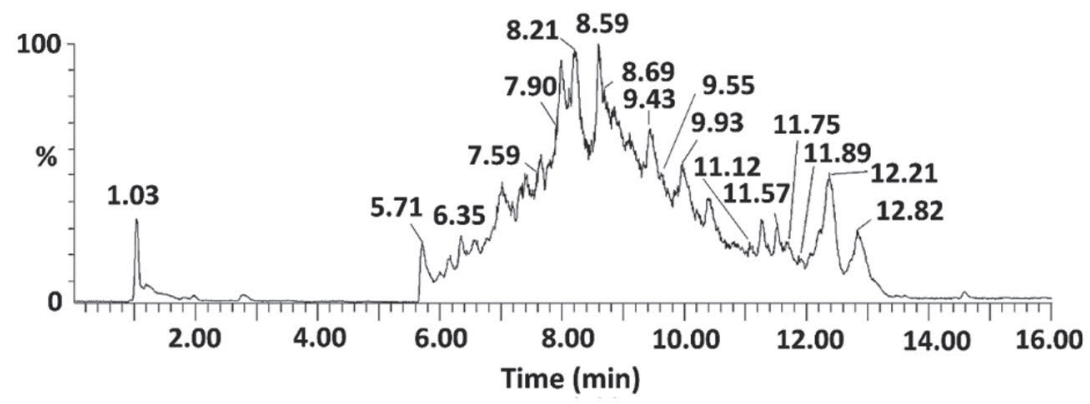

$\mathbf{E}$

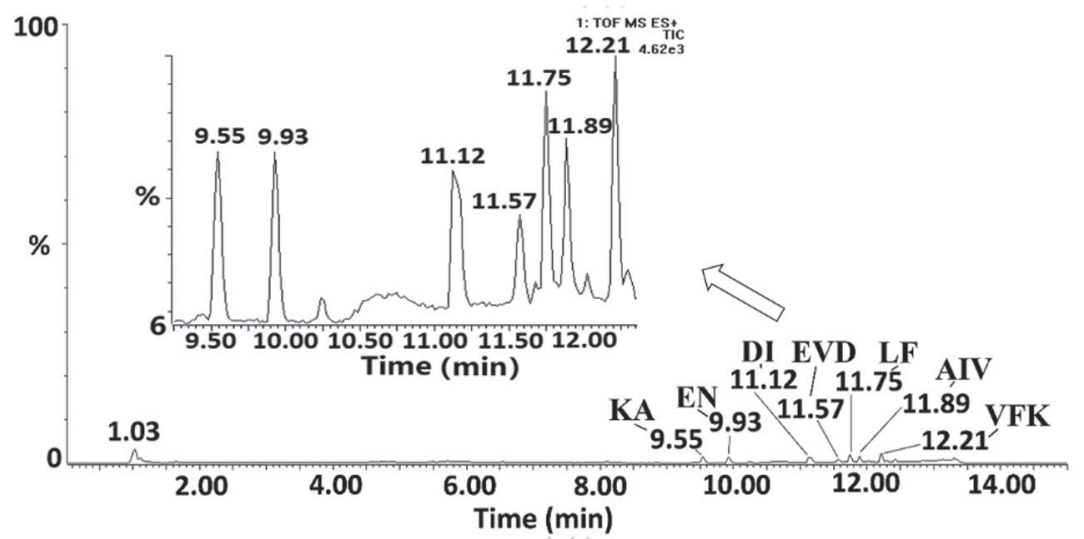

Figure 3. (A) Effect of hydrolysis time on angiotensin-I-converting enzyme (ACE)-inhibitory peptide production using immobilized proteinases. Data are the mean $\pm \mathrm{SE}(\mathrm{n}=3)$ of at least 3 independent experiments. (B) Sephadex-15 (Amersham Pharmacia Biotech, Uppsala, Sweden) chromatography of whey protein hydrolysate (measured as absorbance, A, at $220 \mathrm{~nm}$ ); (C) Sephadex G-10 chromatography of fraction 2 obtained from Sephadex G-15; total ion chromatograms of fraction 1' obtained from Sephadex G-10 before (D) and after (E) transport across Caco-2 cell monolayers. 
A
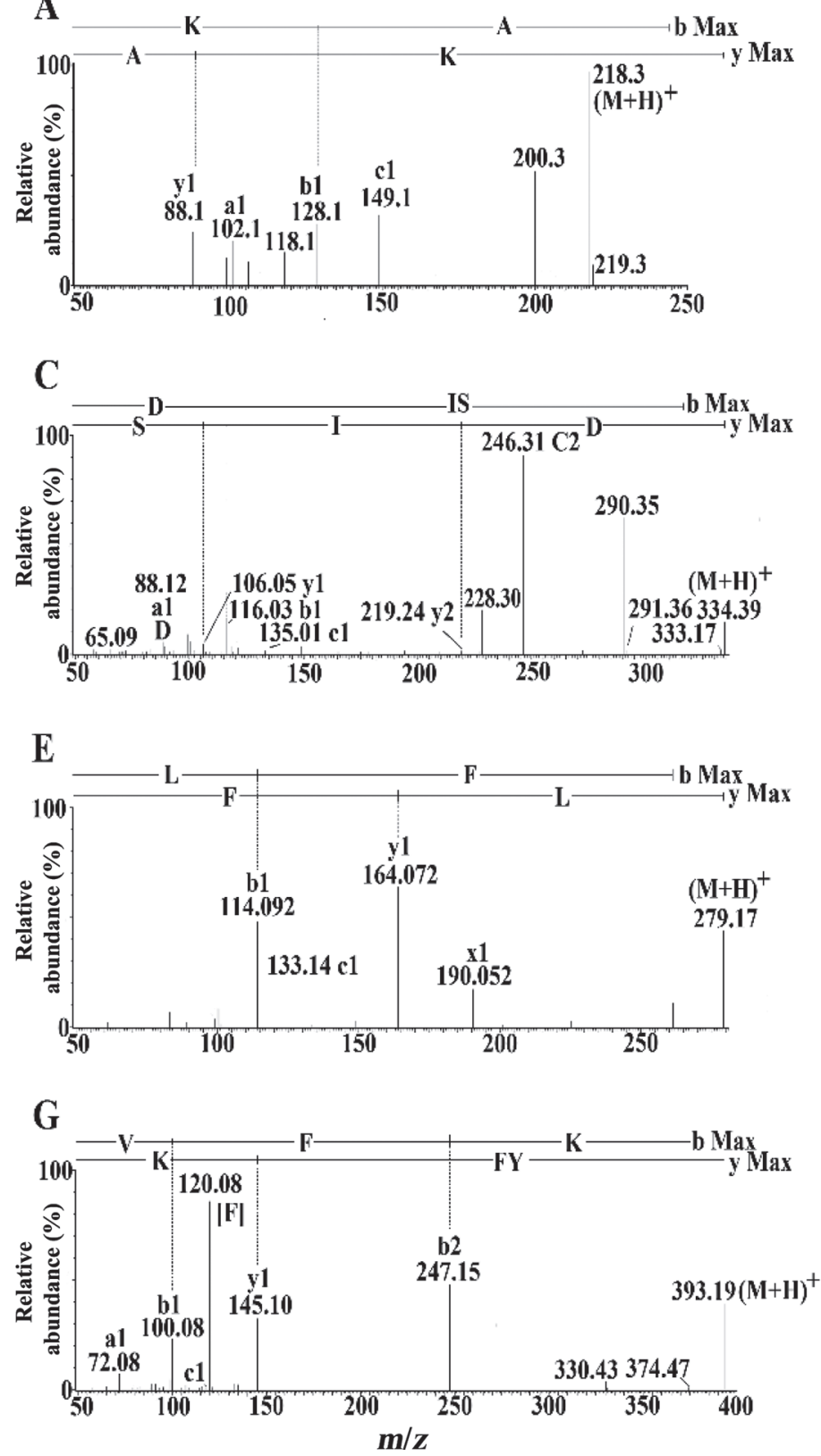
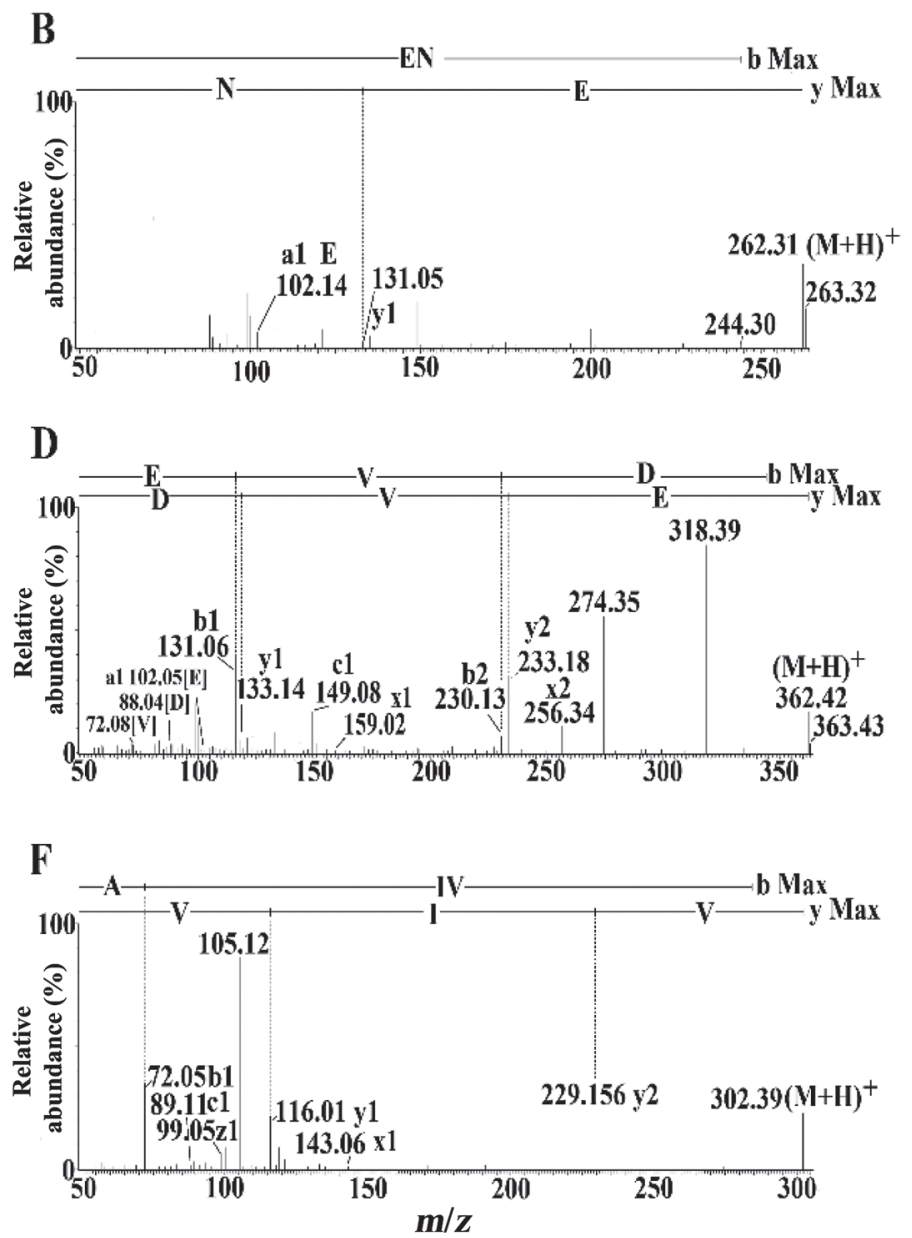

Figure 4. Tandem mass spectra of peptides KA [retention time (RT) $9.55 \mathrm{~min}$; A], EN (RT $9.93 \mathrm{~min}$; B), DIS (RT 11.12 min; C), EVD (RT 11.57 min; D), LF (RT 11.75 min; E), AIV (RT 11.89 min; F), and VFK (RT $12.21 \mathrm{~min} ; \mathrm{G}$ ).

chain peptides are probably degraded by brush-border or cellular peptidases across the intestinal brush-border membrane (Zhu et al., 2008). The 7 transported ACE-inhibitory activity peptides may be the products of long-chain whey hydrolysates degraded by brushborder or cellular peptidases when crossing the Caco-2 cell monolayer. These transported di- and tripeptides with ACE-inhibitory activity would be "true" ACE inhibitors and physiologically important. The peptide
LHLPLP was hydrolyzed by cellular peptidases to HLPLP before transport across the intestinal epithelium and HLPLP was the active form and responsible for the antihypertensive effect (Quirós et al., 2008). Thus, the Caco-2 cell monolayer may be an efficient way to select deliverable peptides from complex protein hydrolysates. Toopcham et al. (2017) also used Caco-2 cell monolayers to screen 6 identified ACE inhibitory peptides, including LLP, AHL, PQP, MCS, GTY, and 
Table 4. Characteristics of angiotensin-I-converting enzyme (ACE)-inhibitory peptides hydrolyzed from whey protein $^{1}$

\begin{tabular}{|c|c|c|c|c|c|c|}
\hline $\mathrm{RT}(\min )$ & $\begin{array}{l}\text { Peptide } \\
\text { sequence }\end{array}$ & $M_{\mathrm{r}}(\mathrm{Da})$ & {$[\mathrm{M}+\mathrm{H}]^{+} m / z$} & GRAVY & $\begin{array}{c}\text { Electrostatic } \\
\text { charge }(\mathrm{pH}=7.0)\end{array}$ & $\begin{array}{c}\mathrm{IC}_{50} \\
(\mathrm{mmol} / \mathrm{L})\end{array}$ \\
\hline 9.55 & KA & 217.27 & 218.3 & -1.05 & 0.86 & $1.24 \pm 0.01$ \\
\hline 9.93 & EN & 261.23 & 262.31 & -3.5 & -0.92 & $1.43 \pm 0.04$ \\
\hline 11.57 & EVD & 361.35 & 362.42 & -0.93 & -2.15 & $1.32 \pm 0.05$ \\
\hline 11.75 & LF & 278.35 & 279.17 & 3.3 & 0.31 & $1.60 \pm 0.39$ \\
\hline 11.89 & AIV & 301.39 & 302.39 & 3.5 & 0.31 & $2.66 \pm 0.02$ \\
\hline
\end{tabular}

${ }^{1} \mathrm{RT}=$ retention time; $M_{\mathrm{r}}=$ molecular weight; GRAVY (grand average of hydropathy) was calculated from www.gravy-calculator.de (positive value represents hydrophobic; negative value represents hydrophilic); electrostatic charge was calculated from http://www.innovagen.se/index .asp; and $\mathrm{IC}_{50}=$ half-maximal inhibitory concentration. Data are the mean $\pm \mathrm{SE}(\mathrm{n}=3)$ of at least 3 independent experiments.

ALSC, from tilapia muscle fractions hydrolyzed by Virgibacillus halodenitrificans SK1-3-7 proteinases.

Aside from molecular weight, hydrophobicity or hydrophilicity also influences susceptibility to peptidases and intestinal absorption (Fernández-Musoles et al., 2013). Hydrophobic (KA, EN, and EVD) and hydrophilic (DIS, LF, AIV, and VFK) peptides were found in BL solution of the Caco-2 cell line (Table 4). It is known that hydrophobic peptides can transport easily across the intestinal epithelium because of the interaction between the peptides and the membrane. Hydrophilic drugs can also be transported across the intestine via the paracellular and transcellular routes (Artursson et al., 1996).

Negatively (EN, DIS, and EVD) and positively (KA, LF, AIV, and VFK) charged peptides were present in the transportation solution of the Caco-2 cell line (Table $4)$. Whether electrostatic charge influences the permeation of ACE-inhibitory peptides across Caco-2 cells is debatable. Pauletti et al. (1997) reported that permeation across the intestinal mucosa of a peptide sample with the same length was charge-dependent (negative $<$ positive $\leq$ neutral), whereas Fernández-Musoles et al. (2013) reported that WQ (neutral charge) had a higher transepithelial flux value across the Caco-2 monolayer than positively charged tripeptides. However, Rubasa et al. (1993) reported that permeation across the cell monolayer of peptide RGD analogs (charges ranging from -3 to +1 ) with negative charges of -1 and -2 was higher than that of analogs with positive charges.

It is generally accepted that di- and tripeptides are easily absorbed in the intestine and transported via the proton-dependent PepT1 transport system (Satake et al., 2002; Vermeirssen et al., 2004). Apart from the PepT1 transport system, peptides can be absorbed intact across the intestinal mucosa via other mechanisms, including paracellular transport and the transcytosis route (Vermeirssen et al., 2002). Paracellular transport may be the main mechanism for the transport of intact VPP across the Caco-2 cell monolayer (Satake et al.,
2002). Further experiments are required to study the transportation ability and route of di- and tripeptides discovered in our study.

\section{CONCLUSIONS}

Angiotensin-I-converting enzyme-inhibitory peptides can be successfully produced from whey protein hydrolyzed by immobilized L. helveticus LB 10 proteinases. Compared with free proteinases, the immobilized proteinases had significantly higher $\mathrm{pH}$, thermal, and storage stabilities. After peptide mixtures were transported across Caco-2 cell monolayers, 7 ACE-inhibitory peptides (KA, EN, DIS, EVD, LF, AIV, and VFK) were identified in the basolateral solution of Caco-2 cell model. This study provides a research basis for the development of bioactive peptide ingredients applied to the functional food market.

\section{ACKNOWLEDGMENTS}

This work was supported by the National Natural Science Foundation of China (31571852, 31471598, 31671869, and 31601487), Natural Science Foundation of Jiangsu Province (BK20151544), and the "333 Project" Foundation of Jiangsu Province (BRA2017450). The authors do not have any conflicts of interest.

\section{REFERENCES}

Abubakar, A., T. Saito, H. Kitazawa, Y. Kawai, and T. Itoh. 1998. Structural analysis of new antihypertensive peptides derived from cheese whey protein by proteinase $\mathrm{K}$ digestion. J. Dairy Sci. 81:3131-3138.

Artursson, P., K. Palm, and K. Luthman. 1996. Caco-2 monolayers in experimental and theoretical predictions of drug transport. Adv. Drug Deliv. Rev. 22:67-84.

Bradford, M. M. 1976. A rapid and sensitive method for the quantitation on microgram quantities of protein utilizing the principle of protein-dye binding. Anal. Biochem. 72:248-254.

Cushman, D. W., and H. S. Cheung. 1971. Spectrophotometric assay and properties of the angiotensin-converting enzyme of rabbit lung. Biochem. Pharmacol. 20:1637-1648. 
Dihal, A. A., R. A. Woutersen, B. van Ommen, I. M. Rietjens, and R. H. Stierum. 2006. Modulatory effects of quercetin on proliferation and differentiation of the human colorectal cell line Caco-2. Cancer Lett. 238:248-259.

Fernández-Musoles, R., J. B. Salom, M. Castelló-Ruiz, M. M. Contreras, I. Recio, and P. Manzanares. 2013. Bioavailability of antihypertensive lactoferricin B-derived peptides: Transepithelial transport and resistance to intestinal and plasma peptidases. Int. Dairy J. 32:169-174.

Foltz, E., S. Azad, M. L. Everett, Z. E. Holzknecht, N. L. Sanders, J. W. Thompson, L. G. Dubois, W. Parker, S. Keshavjee, S. M. Palmer, R. D. Davis, and S. S. Lin. 2015. An assessment of human gastric fluid composition as a function of PPI usage. Physiol. Rep. 3:e12269.

Fu, Y., J. F. Young, M. M. Løkke, R. Lametsch, R. E. Aluko, and M. Therkildsen. 2016. Revalorisation of bovine collagen as a potential precursor of angiotensin I-converting enzyme (ACE) inhibitory peptides based on in silico and in vitro protein digestions. J. Funct. Foods 24:196-206.

Ganaie, M. A., H. K. Rawat, O. A. Wani, U. S. Gupta, and N. Kango. 2014. Immobilization of fructosyltransferase by chitosan and alginate for efficient production of fructooligosaccharides. Process Biochem. 49:840-844.

Guo, Y., J. Gan, Q. Zhu, X. Zeng, Y. Sun, Z. Wu, and D. Pan. 2018. Transepithelial transport of milk-derived angiotensin-I converting enzyme inhibitory peptide with the RLSFNP sequence. J. Sci. Food Agric.98:976-983.

Guo, Y., D. Pan, and M. Tanokura. 2009. Optimisation of hydrolysis conditions for the production of the angiotensin-I converting enzyme (ACE) inhibitory peptides from whey protein using response surface methodology. Food Chem. 114:328-333.

Hernández-Ledesma, B., M. J. García-Nebot, S. Fernández-Tomé, L. Amigo, and I. Recio. 2014. Dairy protein hydrolysates: Peptides for health benefits. Int. Dairy J. 38:82-100.

Hernández-Ledesma, B., M. del Mar Contreras, and I. Recio. 2011. Antihypertensive peptides: Production, bioavailability and incorporation into foods. Adv. Colloid Interface Sci. 165:23-35.

Idris, A., and W. Suzana. 2006. Effect of sodium alginate concentration, bead diameter, initial $\mathrm{pH}$ and temperature on lactic acid production from pineapple waste using immobilized Lactobacillus delbrueckii. Process Biochem. 41:1117-1123.

Jeamjounkhaw, P., A. H-kittikun, and B. Cheirsilp. 2007. Optimization of lipase entrapment in alginate gel bead for palm olein hydrolysis. Songklanakarin J. Sci. Technol. 29(Suppl. 2):3520-3522.

Kumar, S., I. Haq, J. Prakash, and A. Raj. 2017. Improved enzyme properties upon glutaraldehyde cross-linking of alginate entrapped xylanase from Bacillus licheniformis. Int. J. Biol. Macromol. 98:24-33.

LeTien, C., M. Millette, M. Lacroix, and M.-A. Mateescu. 2004. Modified alginate matrices for the immobilization of bioactive agents. Biotechnol. Appl. Biochem. 39(Pt. 2):189-198.

Maeno, M., N. Yamamoto, and T. Takano. 1996. Identification of an antihypertensive peptide from casein hydrolysate produced by a proteinase from Lactobacillus helveticus CP790. J. Dairy Sci. 79:1316-1321.

Meisel, H. 1997. Biochemical properties of bioactive peptides derived from milk proteins: potential nutraceuticals for food and pharmaceutical applications. Livest. Prod. Sci. 50:125-138.

Miguela, M., M. J. Alonsob, M. Salaicesb, A. Aleixandred, and R. López-Fandiñoa. 2007. ACE-inhibitory and vasodilator properties of an egg white hydrolysate: Effect of a simulated intestinal digestion. Food Chem. 104:163-168.

Mineo, H., H. Hara, N. Shigematsu, Y. Okuhara, and F. Tomita. 2002. Melibiose, difructose anhydride III and difructose anhydride IV enhance net calcium absorption in rat small and large intestinal epithelium by increasing the passage of tight junctions in vitro. J. Nutr. 132:3394-3399.

Murakami, M., H. Tonouchi, R. Takahashi, H. Kitazawa, Y. Kawai, H. Negishi, and T. Saito. 2004. Structural analysis of a new antihypertensive peptide ( $\beta$-Lactosin B) isolated from a commercial whey product. J. Dairy Sci. 87:1967-1974.
Nakamura, Y., N. Yamamoto, K. Sakai, A. Okubo, S. Yamazaki, and T. Takano. 1995. Purification and characterization of angiotensin I-converting enzyme inhibitors from sour milk. J. Dairy Sci. 78:777-783.

Nawaz, M. A., H. U. Rehman, Z. Bibi, A. Aman, and S. A. Ul Qader. 2015. Continuous degradation of maltose by enzyme entrapment technology using calcium alginate beads as a matrix. Biochem. Biophys. Rep. 4:250-256.

Pal, A., and F. Khanum. 2011. Covalent immobilization of xylanase on glutaraldehyde activated alginate beads using response surface methodology: Characterization of immobilized enzyme. Process Biochem. 46:1315-1322.

Pan, D., and Y. Guo. 2010. Optimization of sour milk fermentation for the production of ACE-inhibitory peptides and purification of a novel peptide from whey protein hydrolysate. Int. Dairy J. $20: 472-479$

Pan, D., Y. Guo, and X. Jiang. 2011. Anti-fatigue and antioxidative activities of peptides isolated from milk proteins. J. Food Biochem. $35: 1130-1144$

Pauletti, G. M., F. W. Okumu, and R. T. Borchardt. 1997. Effect of size and charge on the passive diffusion of peptides across Caco-2 cell monolayers via the paracellular pathway. Pharm. Res. 14:164168.

Picariello, G., G. Mamone, C. Nitride, F. Addeo, and P. Ferranti. 2013. Protein digestomics: Integrated platforms to study food-protein digestion and derived functional and active peptides. Trends Anal. Chem. 52:120-134.

Quirós, A., A. Dávalos, M. A. Lasunción, M. Ramos, and I. Recio. 2008. Bioavailability of the antihypertensive peptide LHLPLP: Transepithelial flux of HLPLP. Int. Dairy J. 18:279-286.

Raikos, V., and T. Dassios. 2014. Health-promoting properties of bioactive peptides derived from milk proteins in infant food: A review. Dairy Sci. Technol. 94:91-101.

Rubasa, W., M. Cromwella, T. Gadeka, D. Narindraya, and R. Mrsnya. 1993. Structural elements which govern the resistance of intestinal tissues to compound transport. MRS Online Proc. Library Archive $331: 179$.

Sadat-Mekmene, L., M. Genay, D. Atlan, S. Lortal, and V. Gagnaire. 2011. Original features of cell-envelope proteinases of Lactobacillus helveticus. A review. Int. J. Food Microbiol. 146:1-13.

Satake, M., M. Enjoh, Y. Nakamura, T. Takano, Y. Kawamura, S. Arai, and M. Shimizu. 2002. Transepithelial transport of the bioactive tripeptide, Val-Pro-Pro, in human intestinal Caco-2 cell monolayers. Biosci. Biotechnol. Biochem. 66:378-384.

Sonnier, D. I., S. R. Bailey, R. M. Schuster, A. B. Lentsch, and T. A. Pritts. 2010. TNF-alpha induces vectorial secretion of IL-8 in Caco-2 cells. J. Gastrointest. Surg. 14:1592-1599.

Srinivasan, B., A. R. Kolli, M. B. Esch, H. E. Abaci, M. L. Shuler, and J. J. Hickman. 2015. TEER measurement techniques for in vitro barrier model systems. J. Lab. Autom. 20:107-126.

Stevenson, C. L., P. F. Augustijns, and R. W. Hendren. 1999. Use of Caco-2 cells and LC/MS/MS to screen a peptide combinatorial library for permeable structures. Int. J. Pharm. 177:103-115.

Stuknyte, M., S. Cattaneo, F. Masotti, and I. De Noni. 2015. Occurrence and fate of ACE-inhibitor peptides in cheeses and in their digestates following in vitro static gastrointestinal digestion. Food Chem. 168:27-33.

Toopcham, T., J. J. Mes, H. J. Wichers, S. Roytrakul, and J. Yongsawatdigul. 2017. Bioavailability of angiotensin I-converting enzyme (ACE) inhibitory peptides derived from Virgibacillus halodenitrificans SK1-3-7 proteinases hydrolyzed tilapia muscle proteins. Food Chem. 220:190-197.

Toopcham, T., S. Roytrakul, and J. Yongsawatdigul. 2015. Characterization and identification of angiotensin I-converting enzyme (ACE) inhibitory peptides derived from tilapia using Virgibacillus halodenitrificans SK1-3-7 proteinases. J. Funct. Foods 14:435-444. $(\mathrm{J})$.

Tümtürk, H., F. Sahin, and G. Demirel. 2007. A new method for immobilization of acetylcholinesterase. Bioprocess Biosyst. Eng. $30: 141-145$. 
Van der Ven, C., H. Gruppen, D. B. A. De Bont, and A. G. J. Voragen. 2002. Optimisation of the angiotensin converting enzyme inhibition by whey protein hydrolysates using response surface methodology. Int. Dairy J. 12:813-820.

Vermeirssen, V., J. Van Camp, and W. Verstraete. 2004. Bioavailability of angiotensin I converting enzyme inhibitory peptides. Br. J. Nutr. 92:357-366.

Vermeirssen, V., B. Deplancke, K. A. Tappenden, J. Van Camp, H. R. Gaskins, and W. Verstraete. 2002. Intestinal transport of the lactokinin Ala-Leu-Pro-Met-His-Ile-Arg through a Caco-2 Bbe monolayer. J. Pept. Sci. 8:95-100.

Wakai, T., T. Shinoda, N. Uchida, M. Hattori, Y. Nakamura, T. Beresford, R. P. Ross, and N. Yamamoto. 2013. Comparative analysis of proteolytic enzymes need for processing of antihypertensive peptides between Lactobacillus helveticus CM4 and DPC4571. J. Biosci. Bioeng. 115:246-252.
Yamamoto, N., M. Maeno, and T. Takano. 1999. Purification and characterization of an antihypertensive peptide from a yogurt-like product fermented by Lactobacillus helveticus CPN4. J. Dairy Sci. 82:1388-1393

Zhao, F., Q. Wang, J. Dong, M. Xian, J. Yu, H. Yin, Z. Chang, X. Mu, T. Hou, and J. Wang. 2017. Enzyme-inorganic nanoflowers/ alginate microbeads: An enzyme immobilization system and its potential application. Process Biochem. 57:87-94.

Zhou, Z. D., G. Y. Li, and Y. J. Li. 2010. Immobilization of Saccharomyces cerevisiae alcohol dehydrogenase on hybrid alginatechitosan beads. Int. J. Biol. Macromol. 47:21-26.

Zhu, X. L., K. Watanabe, K. Shiraishi, T. Ueki, Y. Noda, T. Matsui, and K. Matsumoto. 2008. Identification of ACE-inhibitory peptides in salt-free soy sauce that are transportable across caco-2 cell monolayers. Peptides 29:338-344 